\title{
The ATP-ADP Exchange Catalyzed by Phosphoryl Transferase ${ }^{1}$
}

\author{
ROBERT E. BEYER² \\ Institute for Enzyme Research, University of Wisconsin, Madison, Wisconsin, and Laboratory of Chemical \\ Biology, Department of Zoology, The University of Michigan, Ann Arbor, Michigan 48104
}

Received January 8, 1968; accepted March 3, 1968

\begin{abstract}
Purified phosphoryl transferase catalyzes an ATP-ADP exchange reaction. Evidence is presented which excludes the possibility that the exchange activity of the preparation is due to contaminating adenylate kinase. The rate of the exchange reaction is affected by the molar ratio of ATP to ADP. The reaction is not highly specific either for the divalent metal ion or for the nucleoside triphosphate which serves as phosphoryl donor. Neither inhibitors of oxidative phosphorylation and electron transfer nor uncouplers of oxidative phosphorylation affect the rate of the exchange reaction significantly. Hydroxylamine in high concentration inhibits the exchange reaction. Phosphoryl transferase does not catalyze several other types of reactions which might be expected to involve protein-bound phosphate as intermediates, such as the reactions catalyzed by pyrophosphatase, alkaline phosphatase and succinylthiokinase, respectively. A previously described protein fraction from mitochondria which inhibited the increase in $P: O$ ratio induced by the phosphoryl transferase also inhibits the ATP-ADP exchange reaction catalyzed by the transferase. The possible role of phosphoryl transferase in the transfer of a phosphoryl group from ATP, formed during oxidative phosphorylation, to exogenous ADP is discussed.
\end{abstract}

Despite significant progress in the understanding of the regulation of mitochondrial reactions, and the formation and utilization of nonphosphorylated intermediary states of oxidative phosphorylation (cf. 1), relatively little direct information is available regarding the transfer of phosphorus, or the catalytic units involved in such transfer reactions, during oxidative phosphorylation. The classic approach for resolving sequential reactions is by way of the isolation of each of

1 This research was supported in part by National Institutes of Health Grants AM 06751 MET, AM BIO 10056 and GM 12847; Institutional Grant \#94 to The University of Michigan from the National Science Foundation; American Cancer Society Institutional Grants IN-40G and Project 94 to The University of Michigan Cancer Research Institute; and a Rackham Faculty Research Fellowship, The University of Michigan. Meat by-products were generously furmished by Oscar Mayer and Co., Madison, Wisconsin. the component enzymes. The isolation of phosphoryl transferase is a step in this type of approach. Phosphoryl transferase, which has been isolated from both $\mathrm{HBHM}^{3}$ and phosphorylating submitochondrial particles (2), increased the phosphorylative capacity of poorly phosphorylating submitochondrial particles (2, $3,4)$. The protein has been shown to be phosphorylated during oxidative phos-

- A portion of this research was performed while the author was the Recipient of a Research Career Development Award (5-K3-GM-4862) from the National Institute of General Medical Science. Present address: Laboratory of Chemical Biology, Department of Zoology, The University of Michigan, Ann Arbor, Michigan 48104.

"Abbreviations: HBHM, heavy beef heart mitochondria; AtctraP, adenosine tetraphosphate; DPT, diphosphothiamine; $\quad \mathrm{F}_{3} \mathrm{CCP}, \quad p$-trifluoromethoxycarbonylcyanidephenylhydrazone; C1-CCP, m-chlorocarbonylcyanidephenylhydrazone; DNP, 2,4-dinitrophenol; PL, asolectin, a crude phospholipid extract from soy beans. 
phorylation in both mitochondrial $(5,6,7)$ and submitochondrial systems (8). The phosphoryl group of the transferase can phosphorylate ADP with the formation of $\operatorname{ATP}(5,6)$. All of these properties would be consistent with a role in the terminal reactions of oxidative phosphorylation, viz.,

$$
\begin{array}{r}
\mathrm{X} \sim \mathrm{P}+\mathrm{E} \Leftrightarrow \mathrm{E} \sim \mathrm{P}+\mathrm{X} \\
\mathrm{E} \sim \mathrm{P}+\mathrm{ADP} \Leftrightarrow \mathrm{ATP}+\mathrm{E}
\end{array}
$$

according to Lehninger (9, p. 95). Since reaction [2] implies that $\mathrm{E}$ should also catalyze an exchange between ATP and ADP, the ability of phosphoryl transferase to catalyze such an exchange reaction has been studied and reported herein. Some of these data have been the subject of a preliminary communication (10) .

\section{METHODS}

HBHM were prepared according to the large scale procedure of Crane, Glenn, and Green (11), the light and heavy layers being separated accord- ing to Hatefi and Lester (12). Phosphoryl transferase was prepared according to Beyer $(2,4)$, and was used at two stages of purity in these studies (4). The enzyme at stage $C$, approximately $85 \%$; pure, is the fraction obtained after DEAE-chromatography; the enzyme at stage $D$, homogenous in the ultracentrifuge, corresponds to the fraction obtained by molecular sieve chromatography on the polyacrylamide gel BioGel P-200. Salt-free hydroxylamine was prepared according to Beinert et al. (13). Adenine nucleotides were separated on $1 \times 0.5 \mathrm{~cm}$ (internal diameter) columns of Dowex 1-formate as described by Brierley and $O^{\prime}$ Brien (14). The identity of each nucleotide fraction was checked from time to time by paper chromatography of authentic nucleotide in the Pabst system I (15). Radioactivity was counted on a thin-window continuous gas-flow counter $(\mathrm{Nu}-$ clear Chicago) or a low-background $(<2$ counts per minute) thin-window continuous gas-flow counter (Nuclear Chicago). Protein was estimated by a biuret procedure (16).

Reduced coenzyme $Q$ was prepared according to the method of Green and Burkhard (19) modified as follows: ten $\mathrm{mg}\left(12 \mu\right.$ moles) of coenzyme $\mathrm{Q}_{10}$ dissolved in $2 \mathrm{ml}$ ethanol and $5 \mathrm{ml}$ of cyclohexane (spectroscopic grade) were added to a graduated

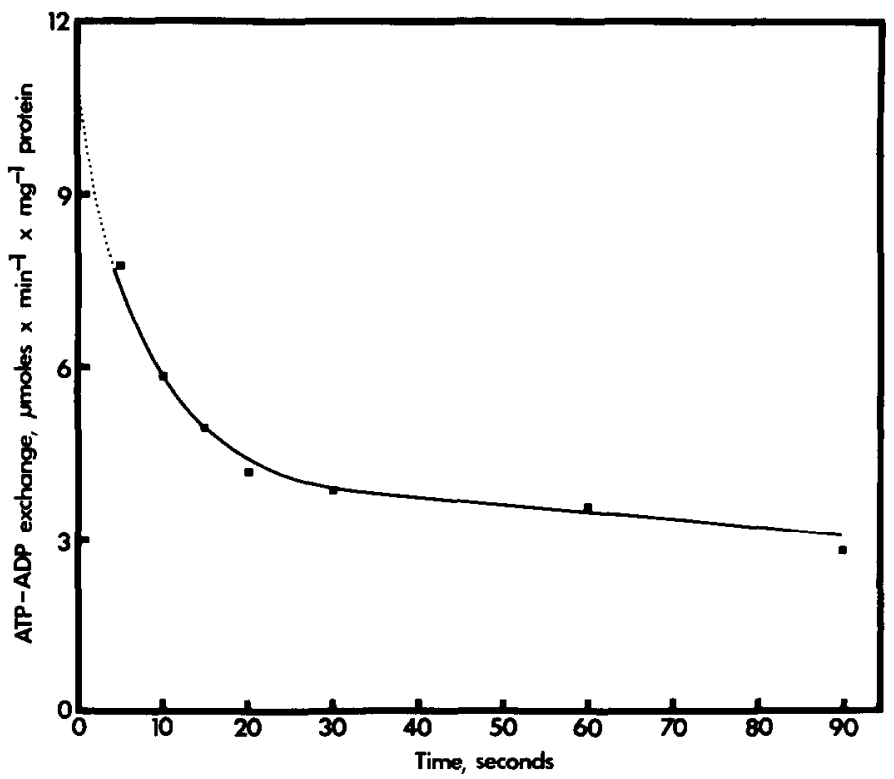

Fic. 1. The initial rate of ATP-ADP exchange. The reaction medium contained in $4 \mathrm{ml}: 16$ $\mu$ moles ATP; $1.6 \mu$ moles ADP (labcled in the $\alpha$ position with ${ }^{3} \mathrm{P}, 153000 \mathrm{cts} \times \mu$ mole ${ }^{-1}$ ); 120 $\mu$ moles imidazole, $\mathrm{pH} 6.8 ; 20 \mu$ moles $\mathrm{MgCl}_{2}$. The reaction mixture was brought to and maintained at $30^{\circ}$ and the reaction was initiated by the addition of $0.13 \mathrm{mg}$ phosphoryl transferase at stage D. Portions $(0.5 \mathrm{ml})$ were removed and added to $0.2 \mathrm{ml}$ of $0.5 \mathrm{~m}$ EDTA to stop the reaction. The mixture was diluted to $50 \mathrm{ml}$ with water, applied to Dowex 1 -formate, and AMP, ADP, and ATP isolated (14). ATP-ADP exchange was calculated from counts appearing in ATP after correction for counts appearing in AMP. The dashed line represents cxtrapolation to zero time. 


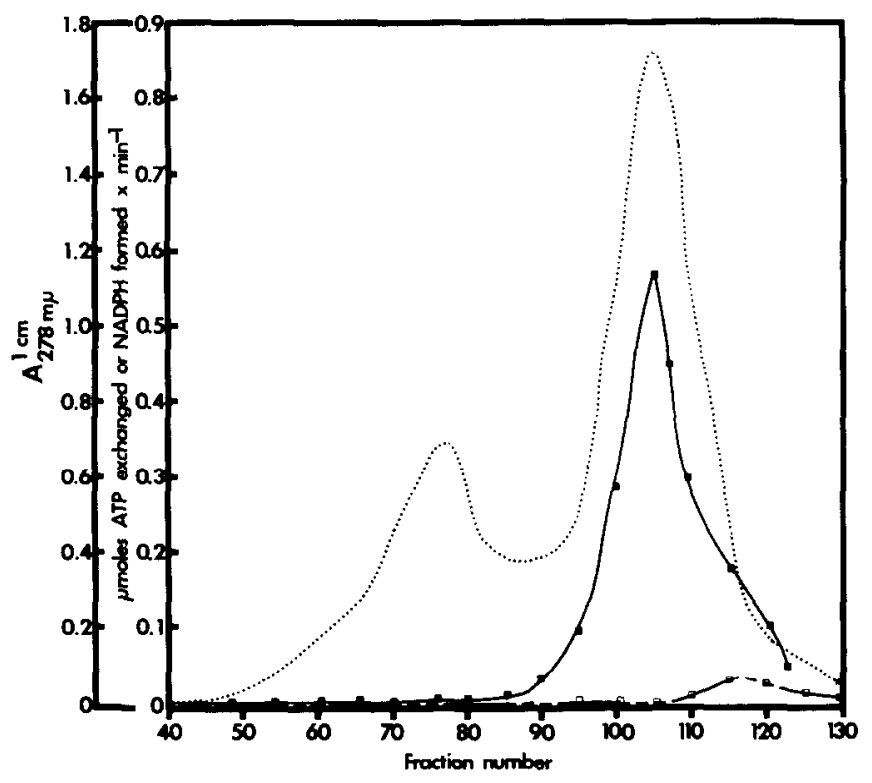

FIG. 2. The rates of exchange and kinase activities during chromatography of a crude transferase preparation. Phosphoryl transferase (352 $\mathrm{mg}$ of a stage $\mathrm{C}$ preparation) in a volume of $22 \mathrm{ml}$ of $50 \mathrm{~mm}$ Tris-sulfate, $\mathrm{pH} 7.5$, was applied to a column $(4 \times 105 \mathrm{~cm})$ of polyacrylamide gel P.200 previously equilibrated with $50 \mathrm{~mm}$ Tris-sulfate, $\mathrm{pH}$ 7.5. The column was developed at a rate of approximately $5 \mathrm{ml}$ per hour with $50 \mathrm{~mm}$ Tris-sulfate, $\mathrm{pH} 7.5$, and $7 \mathrm{ml}$ fractions collected. Chromatography was carried out at $2^{\circ}$. Absorbancy of the eluates was recorded at 278 $\mathrm{m} \mu$ in cuvettes with a $1-\mathrm{cm}$ path. ATP-ADP exchange was assayed as described in the legend of Fig. 1 except that the volume of the assay was $1 \mathrm{ml}$, the amount of protein in each assay was $0.04 \mathrm{mg}$, and the time of incubation was 5 minutes. Adenylate kinase was assayed according to the method of Chappell and Crofts (17), each assay tube containing $0.04 \mathrm{mg}$ protein. Antimycin A, which was included in the assay mixture by Chappell and Crofts (17), was omitted. The absorbancy $\left(\mathrm{A}_{278 \mathrm{~m} \mu}^{1} \mathrm{~cm}\right)$ is represented by $\ldots$; ATP-ADP exchange activity by $\square$; adenylate kinase activity by

cylinder containing $20 \mathrm{ml}$ of $0.25 \mathrm{M}$ sucrose, $20 \mathrm{ml}$ м $\mathrm{P}_{\mathrm{i}}(\mathrm{pH} 7.5)$ and $30 \mathrm{ml}$ of ethanol. $\mathrm{Na}_{2} \mathrm{~S}_{2} \mathrm{O}_{4}$ was added and the mixture shaken until the cyclohexane phase was colorless. The cyclohexane phase was removed and the aqueous phase extracted thrice with $5 \mathrm{ml}$ portions of cyclohexane. To the combined cyclohexane solution was added one drop of a mixture containing $0.1 \mathrm{ml}$ of $0.1 \mathrm{~N} \mathrm{HCl}$ and $0.4 \mathrm{ml}$ ethanol. The solution was taken to dryness in a rotary evaporator under reduced pressure, dissolved in 5 $\mathrm{ml}$ ethanol, and evaporated again. The reduced $\mathrm{co}^{-}$ enzyme $Q_{10}$ was dissolved in $2 \mathrm{ml}$ ethanol, one drop of the acid ethanol added, and the solution was stored at $-20^{\circ}$ under nitrogen.

$\alpha\left({ }^{32}\right.$ P)ATP was purchased from International Chemical and Nuclear Corporation. Its purity was established in the chromatographic system I of Pabst (15). Other nucleotides were purchased from Sigma Chemical Co. Asolectin was purchased from Associated Concentrates, Inc., and was microdispersed according to the ultrasonic irradiation procedure described by Fleischer and Fleischer (20).

\section{RESULTS}

Initial rate of the $A T P-A D P$ exchange reaction. Phosphoryl transferase at stage $\mathrm{D}$ of purity catalyzed an exchange between ADP and A'TP (Fig. 1). In agreement with previously published data (10) on less purified phosphoryl transferase, the rate diminished with time during the initial stage of the reaction; thereafter the decline in activity was small. Both the initial (extrapolated) and final rates of exchange catalyzed by transferase at the stage D level of purity were greater per $\mathrm{mg}$ of protein than the rates catalyzed by the less pure enzyme (stage C) (10) The initial rate of the reaction varied between 8 and $12 \mu$ moles $\times \min ^{-1} \times \mathrm{mg}^{-1}$ protein depending upon the particular preparation of stage $D$ transferase being 


\section{TABLE I}

Adenylate Kinase and ATP-ADP Exchange Activities Catalyzed by Adenylate Kinase of Rabrit Musclif

The concentrations of components in the ATP. ADP exchange assay are given in the legend of Fig. 1. The final volume of the assay mixture was $0.75 \mathrm{ml}$. The reaction was terminated after 10 minutes at $30^{\circ}$ by the addition of $0.2 \mathrm{ml}$ of $0.5 \mathrm{M}$ EDTA. Adenylate kinase activity was assayed spectrophotometrically according to Chappell and Crofts (17) as described in the legend of Fig. 2 . The adenylate kinase (rabbit muscle) was supplied by Boehringer and Sons. The sample was reported to have a specific activity of $670 \mathrm{EU} / \mathrm{mg}$ protein.

\begin{tabular}{ccc}
\hline \multirow{2}{*}{$\begin{array}{c}\text { Enzyme added, } \\
\mathrm{mg} \times 10^{-3}\end{array}$} & \multicolumn{2}{c}{ Activity, $\mu$ moles $\times \mathrm{min}^{-1} \times \mu \mathrm{g}^{-1}$} \\
\cline { 2 - 3 } & ATP-ADP exchange & Adenylate kinase \\
\hline 1 & 0.279 & 0.062 \\
2 & 0.254 & 0.077 \\
4 & 0.266 & 0.068 \\
\hline
\end{tabular}

assayed, while values for routine assays over a period of 5-10 minutes (steady state) varied between 0.2 and $0.6 \mu$ moles $\times \min ^{-1} \times \mathrm{mg}^{-1}$ protein.

Adenylate kinase and $A T P-A D P$ exchange. Preparations of phosphoryl transferase at the level of purity of stage $C$ contained adenylate kinase (EC 2.7.4.3, ATP:AMP phosphotransferase) activity, although such activity was low under the particular assay conditions employed (10). In an effort to assess the participation of adenylate kinase in the exchange activity manifested by preparations of phosphoryl transferase we compared the ADP-ATP exchange reaction and the adenylate kinase reaction (transfer of a phosphoryl group from one molecule of ADP to another molecule of ADP) with a transferase preparation at the highest purity level, i.e. the preparation of the transferase after

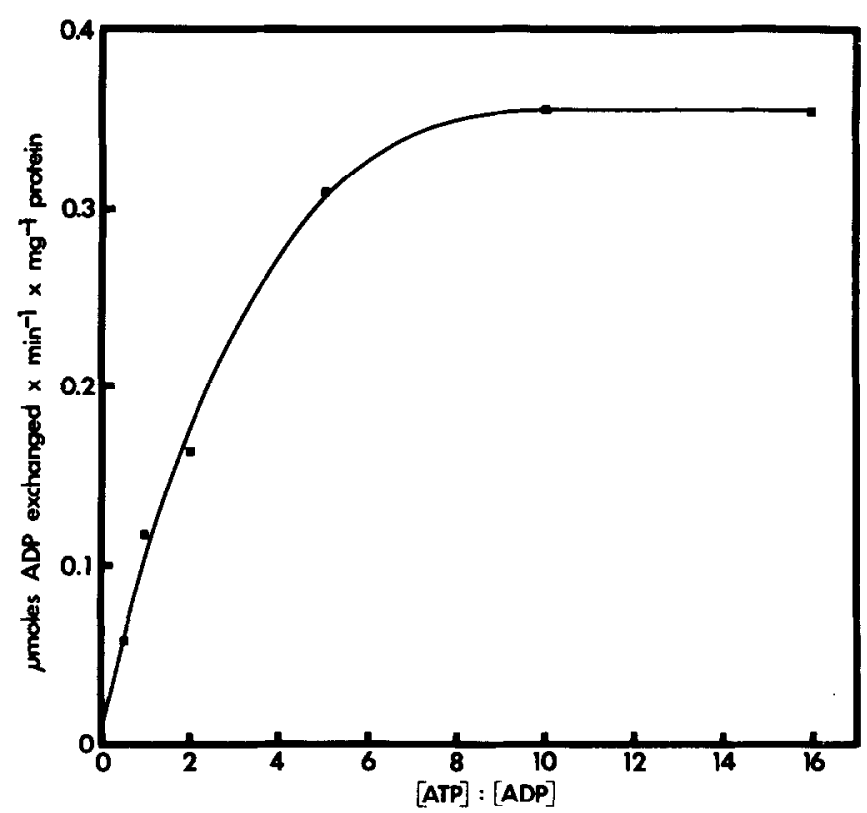

FIG. 3. Variation of the ratio of [ATP] to [ADP] on the rate of ATP-ADP exchange catalyzed by phosphoryl transferase. Each reaction tube contained in a volume of $0.65 \mathrm{ml}: 0.6 \mu$ mole $\alpha$-( $\left.{ }^{4} \mathrm{P}\right)$ ADP (ca. $800000 \mathrm{cts} \times \mathrm{min}^{-1} \times \mu$ mole $^{-1}$ ), pH 6.8; $3 \mu$ moles imidazole, pH 6.8; $5 \mu$ moles $\mathrm{MgCl}_{*}$; and $0.1 \mathrm{mg}$ phosphoryl transferase at stage D. The amount of ATP varied from 0 to 9 $\mu$ moles. The reaction was initiated by the addition of enzyme, maintained at $30^{\circ}$ for 5 minutes, and terminated by the addition of $0.1 \mathrm{ml}$ of $0.5 \mathrm{M}$ EDTA. The rate of ATP-ADP exchange was determined as described in the legend of Fig. 1. 


\section{TABLE II}

Requirement of Divalent Metal IONS FOR ATP-ADP EXChaNGE

Assays were performed as described in the legend of Fig. 3 except that $0.05 \mathrm{mg}$ of phosphoryl transferase at stage D was used and $\mathrm{Mg}^{++}$was added only where indicated in the Table. The metal ion (.5 mM) was added as the chloride except for iron. which was added as ferrous ammonium sulfate. No correction was made for adenylate kinase activity, which was less than $2 \%$ of the ATP-ADP exchange rate.

\begin{tabular}{cc}
\hline Ion added & $\begin{array}{c}\text { Exchange rate, } \\
\text { m } \text { moles }^{-1} \text { min }^{-1} \times \mathrm{mg}^{-1}\end{array}$ \\
\hline $\mathrm{None}$ & 0 \\
$\mathrm{Mg}^{++}$ & 362 \\
$\mathrm{Co}^{++}$ & 227 \\
$\mathrm{Mn}^{++}$ & 202 \\
$\mathrm{Ni}^{++}$ & 189 \\
$\mathrm{Fe}^{++}$ & 107 \\
$\mathrm{Cd}^{++}$ & 77 \\
$\mathrm{Ca}^{++}$ & 46 \\
$\mathrm{Cu}^{++}$ & 0 \\
\hline
\end{tabular}

\section{TABLE III}

Specificity of Phosphoryl Donor in the Exchange: Reaction Catalyzled by Phosphoryl Transferase

The exchange reaction was assayed as described in the legend of Fig. 3 except that $30 \mu \mathrm{g}$ of phosphoryl transferase at stage D was used as enzyme. ATP and compounds tested as potential phosphoryl donors were at a final concentration of 6 $\mu$ moles per $0.65 \mathrm{ml}$. Reaction proceeded for $10 \mathrm{~min}-$ utes at $30^{\circ}$.

\begin{tabular}{clcc}
\hline $\begin{array}{c}\text { Ex- } \\
\text { periment }\end{array}$ & $\begin{array}{c}\text { Phosphoryl donor } \\
\text { (ADP as } \\
\text { acceptor) }\end{array}$ & $\begin{array}{c}\text { Exchange activity, } \\
\text { m } \mu \text { moles/min } / m g \\
\text { protein }\end{array}$ & $\begin{array}{c}\text { \% of rate } \\
\text { with ATP }\end{array}$ \\
\hline \multirow{2}{*}{1} & ATP & 371 & 100 \\
& ITP & 266 & 72 \\
& GTP & 191 & 51 \\
& UTP & 160 & 43 \\
& CTP & 92 & 25 \\
& dATP & 328 & 88 \\
& dUTP & 61 & 16 \\
2 & & & \\
& ATP & 359 & 100 \\
& AtetraP & 72 & 20 \\
& DPT & $<8$ & - \\
& Acetyl P & 12 & 3 \\
& NADP & $<8$ & - \\
& PP & $<8$ & - \\
\hline
\end{tabular}

chromatography on polyacrylamide gel P-200. Although a small amount of adenylate kinase activity was observed in the active fraction, the elution pattern suggested that the protein peak which carried the highest exchange activity was not the peak which corresponded to the adenylate kinase activity (Fig. 2). The lack of coincidence in the elution patterns of the two enzymic activities made it unlikely that the ATD-ADP exchange activity in preparations of phosphoryl transferase could be entirely a reflection of the presence in the preparation of adenylate kinase.

In order to ensure that the assay used to measure adenylate kinase activity in the fraction in which the specific ATPADP exchange activity reached a peak was sufficiently sensitive, both enzymic activities were measured with adenylate kinase under conditions identical with those described in the legend of Fig. 2 (Table I). The kinase tested was isolated from rabbit muscle (purchased from C. F. Boehringer and Sons). The ratio of exchange activity to kinase activity was very much greater for the transferase than for the authentic kinase under essentially identical assay conditions (c.f. Fig. 2). These data, together with the difference in elution patterns between the two enzymic activities (Fig. 2) make it unlikely that the exchange activity of phosphoryl transferase is due to contamination by adenylate kinase.

$A T P: A D P$ ratio and the rate of exchange. Variation in the ratio of [ATP]: $[A D P]$ had a profound effect on the rate of the ATP-ADP exchange reaction catalyzed by phosphoryl transferase (Fig. 3). In confirmation of previously published data (10) for phosphoryl transferase preparations of lower purity, as well as for a highly purified ATD-ADP exchange enzyme from beef liver mitochondria (18), the exchange activity of the purified transferase was found to be increased as the $[\mathrm{ATP}]:[\mathrm{ADP}]$ value was increased until a limiting rate was reached. With phosphoryl transferase of beef heart 
TABLE IV

\section{Effect of Inhibitors on the ATP-ADP Exchange Reaction Catalyzed by Phosphoryl Transferase}

ATP-ADP exchange was assayed as described in the legend of Fig. 3. Phosphoryl transferase at stage $\mathrm{C}$ was used in all cases, approximately $180 \mu \mathrm{g}$ of enzyme being used for each assay. Each assay tube, containing $0.65 \mathrm{ml}$ of reaction mixture, was incubated for 10 minutes at $30^{\circ}$. All rates were corrected for adenylate kinase activity as described in the legend of Fig. 1. When the effect of $\mathrm{HgCl}_{2}, \mathrm{AgNO}_{3}$, or arsenate in Experiment 2 was tested, the enzyme was preincubated with the compound for 10 min at $0^{\circ}$ prior to making other additions and initiating the reaction.

\begin{tabular}{|c|c|c|c|}
\hline Experiment & Addition & Concentration, $\mathbf{x}$ & $\begin{array}{l}\text { Exchange activity, } \\
\mathrm{m} \mu \mathrm{moles} / \mathrm{min} / \mathrm{mg}\end{array}$ \\
\hline \multirow[t]{3}{*}{1} & - & - & 191 \\
\hline & $\mathrm{F}_{2} \mathrm{CCP}$ & $10^{-5}$ & 186 \\
\hline & $\mathrm{Cl}-\mathrm{CCP}$ & $10^{-4}$ & 185 \\
\hline \multirow[t]{9}{*}{2} & - & - & 173 \\
\hline & DNP & $5 \times 10^{-4}$ & 167 \\
\hline & Cysteine & $10^{-4}$ & 169 \\
\hline & $\mathrm{HgCl}_{2}$ & $5 \times 10^{-5}$ & 164 \\
\hline & $\mathrm{HgCl}_{2}+$ cysteine & $5 \times 10^{-5}, 10^{-4}$ & 157 \\
\hline & $\mathrm{AgNO}_{3}$ & $5 \times 10^{-5}$ & 187 \\
\hline & $\mathrm{AgNO}_{3}+$ cysteine & $5 \times 10^{-5}, 10^{-4}$ & 159 \\
\hline & Arsenate & $10^{-2}$ & 151 \\
\hline & Arsenate + cysteine & $10^{-2}, 10^{-4}$ & 159 \\
\hline \multirow[t]{3}{*}{3} & - & - & 176 \\
\hline & Atractyloside & $4 \times 10^{-5}$ & 182 \\
\hline & $P_{i}$ & $10^{-3}$ & 193 \\
\hline \multirow[t]{2}{*}{4} & - & - & 178 \\
\hline & Oligomycin & $3 \times 10^{-4}$ & 161 \\
\hline \multirow[t]{6}{*}{5} & - & - & 206 \\
\hline & $\mathrm{CoQ}_{10}$ & $93 \mu \mathrm{M}$ & 208 \\
\hline & $\mathrm{CoQH}_{2} 10$ & $93 \mu \mathrm{M}$ & 214 \\
\hline & PL & $1 \mathrm{mg}$ & 207 \\
\hline & $\mathrm{PL}+\mathrm{CoQ} 10$ & $1 \mathrm{mg}+93 \mu \mathrm{M}$ & 209 \\
\hline & $\mathrm{PL}+\mathrm{CoQH}_{2} 10$ & $1 \mathrm{mg}+93 \mu \mathrm{M}$ & 199 \\
\hline
\end{tabular}

mitochondria the optimal ratio appeared to be 8; for the beef liver exchange enzyme of Wadkins and Glaze approximately 2 (18). A ratio of 10 has been employed in the experiments reported herein.

Divalent ions and the ATP-ADP exchange reaction. It had been reported previously (10) that the ATP-ADP exchange reaction catalyzed by phosphoryl transferase (stage C) showed little specificity for the divalent metal ion requirement. A comparable low order of specificity for the divalent metal ion was found to apply to the exchange reaction catalyzed by the more purified transferase (Table II). The metal ions were tested at a concentration which had been shown to be optimal for $\mathrm{Mg}^{++}$, i.e. $5 \mathrm{~mm}$. All of the ions tested, with the exception of $\mathrm{Cu}^{++}$, showed some ability to support the reaction. $\mathrm{Mg}^{+-}$was the most effective of the divalent ions tested.

Nucleotide specificity of the exchange reaction. It was of interest to study the ability of phosphoryl transferase to catalyze the transfer of a phosphoryl group from various phosphoryl donors to ADP (Table III). Once again, as in the case of the requirement for divalent metal ions, the specificity for the phosphoryl donor 


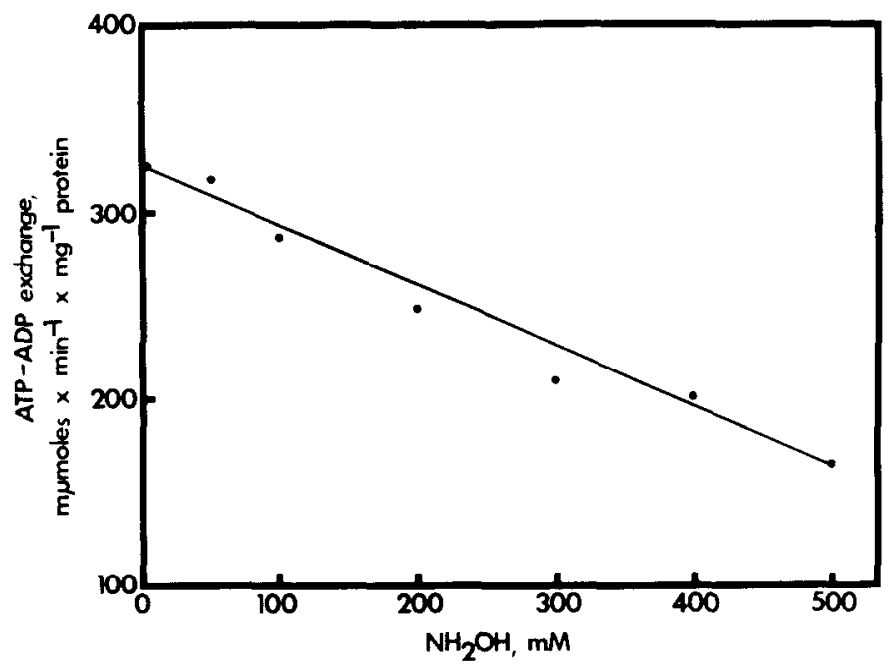

FIG. 4. Inhibition of ATP-ADP exchange activity by hydroxylamine. The reaction was assayed as described in the legend for Fig. 3. Each assay tube contained $0.6 \mu$ mole ADP and $6 \mu$ moles ATP.

\section{TABLE 1}

Thists for Enzymic Activities in Preparations of Phosphoryl Traxsfirise (Stige D)

All assays were carried out at $30^{\circ}$. Inorganic pyrophosphatase was assayed for 60 minutes in the following medium: imidazole ( $\mathrm{pH} 6.8$ ), 30 $\mu$ moles; $\mathrm{PP}_{\mathrm{i}}$ (pH 6.8), $10 \mu$ moles; $\mathrm{MgCl}_{2}, 15$ $\mu$ moles; enzyme, $0.3 \mathrm{mg}$; total volume, $3.0 \mathrm{ml} . \mathrm{P}_{\mathrm{i}}$ production was measured according to Lindberg and Ernster (24). Other reactions were assayed according to the references cited except that 0.2 mg of enzyme was present in the alkaline phosphatase assay and its duration was 60 minutes. Hydroxamate was measured according to Beinert et al. (13) and succinyl thiokinase activity was assayed with both ATP and GTP present. $P_{i}$-ATP exchange assays contained $0.2 \mathrm{mg}$ enzyme and were terminated after 30 minutes. Succinyl thiokinase was assayed with preparations of stage $D$ phosphoryl transferase as enzyme. In the other three enzyme assays the transferase preparations were at the level of purity of stage $C$.

\begin{tabular}{lcc}
\hline \multicolumn{1}{c}{ Activity tested } & $\begin{array}{c}\text { Activity, } \\
\text { m } \mu \text { moles } \\
\text { product/assay }\end{array}$ & $\begin{array}{c}\text { Reference for } \\
\text { assay system }\end{array}$ \\
\hline Pyrophosphatase & 0 & - \\
Alkaline phosphatase & 0 & $(22)$ \\
Succinyl thiokinase & $<0.01$ & $(23)$ \\
${ }^{32} \mathrm{P}_{\mathrm{i}}$-ATP exchange & $<0.001$ & $(24)$ \\
\hline
\end{tabular}

in the exchange reaction was low. ATP was the most effective phosphoryl donor of the compounds tested. dATP and ITP were also effective phosphoryl donors,

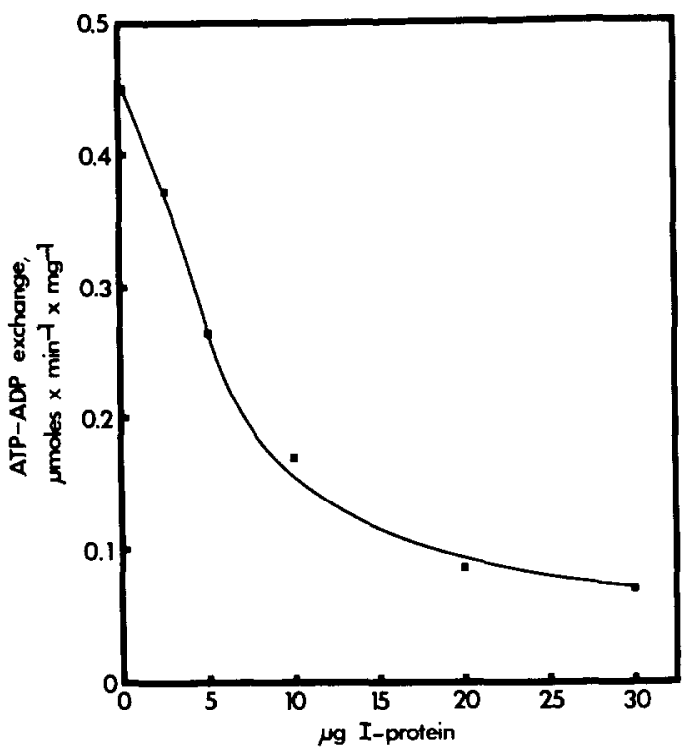

FIg. 5. Inhibition of ATP-ADP exchange activity by I-protein. The reaction was assayed as described in the legend for Fig. 3. Each assay tube contained $0.6 \mu$ mole ADP, $6 \mu$ moles ATP, and $200 \mu \mathrm{g}$ phos phoryl transferase at stage $\mathrm{D}$.

being 87 and 78 ; respectively, as active as ATP. It was also of interest to note that adenosine tetraphosphate, which has one phosphate group additional to that in ATP, was only $20^{\circ} \%$ as effective as ATP as a phosphoryl donor (Expt. 2, Table III). 
Inorganic pyrophosphate did not show significant activity as a phosphoryl donor. Clearly the purine or pyrimidine ring of the phosphoryl donor molecule plays an important role in determining interaction with the transferase.

Inhibitors and the ATP-ADP exchange. In an attempt to obtain information on the possible role of phosphoryl transferase in mitochondrial function, a number of inhibitors and uncouplers of oxidative phosphorylation, as well as other active compounds, have been tested for their influence on the rate of the ATP-ADP exchange reaction catalyzed by phosphoryl transferase (Table IV). Uncouplers, such as DNP, $\mathrm{F}_{3} \mathrm{CCP}$, and $\mathrm{Cl}-\mathrm{CCP}$, were without significant effect on the rate of the ATP-ADP exchange reaction. Compounds which would be expected to interact with disulfide bonds and sulfhydryl groups, such as $\mathrm{AgNO}_{3}, \mathrm{HgCl}_{2}$, and cysteine, were also without effect. Arsenate, which might be expected to interfere with the exchange reaction if inorganic orthophosphate participated in the reaction, did not affect the reaction significantly. The nonparticipation of $P_{i}$ in the reaction was indicated also by the lack of effect of $P_{i}$ on the reaction. It might be noted that in an experiment in which ${ }^{32} \mathrm{P}_{i}$ was included in the reaction medium, and in which $\mathrm{ADP}$ was added without radioactive label, no radioactivity was found in any of the nucleotide fractions, again indicating that the reacting species in the exchange reaction were not in equilibrium with $\mathrm{P}_{\mathrm{i}}$. Two inhibitors of oxidative phosphorylation, oligomycin and atractyloside, were also without significant effect on the rate of the exchange reaction catalyzed by the transferase. It was thought of interest to study the possible effect of a member of the electron transfer chain on the rate of the ATP-ADP exchange reaction in order to ascertain whether any interaction could take place which might be reflected on the rate of the reaction. Neither oxidized nor reduced coenzyme $Q_{10}$ in the presence or the absence of phospholipid, significantly affected the rate of the reaction.

Hydroxylamine and ATP-ADP exchange. Hydroxylamine has been reported to inhibit the transfer of a phosphoryl group from transferase to $\operatorname{ADP}(6)$. Since it appears likely that both the transfer of a phosphoryl group to ADP and the ATP. ADP exchange reaction are catalyzed by the same protein, the effect of hydroxylamine on the rate of the ATP-ADP exchange reaction was studied (Fig. 4). The presence of $\mathrm{NH}_{2} \mathrm{OH}$ at concentrations greater than $0.1 \mathrm{M}$ resulted in progressive inhibition of the exchange reaction. The inhibition of the exchange reaction by hydroxylamine was consistent with the previously reported inhibition of the transfer of a phosphoryl group from the transferase to ADP (6), both activities being inhibited by about $26 \%$ at $0.25 \mathrm{M}$ $\mathrm{NH}_{2} \mathrm{OH}$.

Assay of the phosphoryl transferase preparation for other enzymic reactions. A series of experiments was undertaken to test the possibility that the ATP-ADP exchange reaction catalyzed by purified preparations of phosphoryl transferase was, in fact, attributable to a protein other than the one responsible for the major elution peak from DEAE-cellulose and the polyacrylamide gel P-200. Evidence has been presented above (Fig. 2) that adenylate kinase was not a contamination responsible for the ATP-ADP exchange. In conjunction with Dr. Gottfried Schatz, phosphoryl transferase had been shown to be incapable of catalyzing the hydrolysis of ATP (2). The enzymic activitics tested for in purified preparations of the transferase are listed in Table V. None were catalyzed to any measurable extent by the transferase preparations.

Effect of inhibitor protein on ATP-ADP exchange. Previous experiments had shown that in the final step in the purification of phosphoryl transferase, i.e. chromatography on polyacrylamide gel P-200, a protein was separated from phosphoryl transferase which inhibited the increase in $\mathrm{P}: \mathrm{O}$ ratio of submitochondrial particles induced by addition of phosphoryl transferase (2). In order to study the inhibition phenomenon in greater detail the effect of the I-protein on the ATP-ADP exchange reaction catalyzed by stage $D$ phosphoryl transferase was determined 
at various concentrations of the I-protein (Fig. 5). Half maximal inhibition in the experiment depicted in Fig. 5 was obtained with $5 \mu \mathrm{g}$ of I-protein. The weight ratio of phosphoryl transferase to I-protein was 40 at the point of half maximal inhibition. Complete inhibition of the exchange reaction was not achieved even when the concentration of I-protein was further increased by a factor of 13 .

\section{DISCUSSION}

The results of the above study indicate that phosphoryl transferase catalyzes reversibly the transfer of a phosphoryl group from ATP to ADP, a reaction commonly referred to as an ATP-ADP exchange. The rate of the reaction diminished rapidly with time; this decay in rate parallels that reported for an exchange enzyme from liver mitochondria (25). The rate of the exchange reaction was affected by the molar ratio of ATP:ADP. Inhibitors of oxidative phosphorylation and of electron transfer and uncouplers of oxidative phosphorylation had no influence on the exchange reaction. However, hydroxylamine to a small degree and the I-protein to a high degree inhibited the activity of the transferase. The inhibitory action of hydroxylamine might suggest the involvement of a carboxyl group of the enzyme in the transferase activity. We have previously reported $(5,6)$ the sensitivity to hydroxylamine of the transfer of a phosphoryl group from the transferase to ADP. The inhibition of the exchange reaction by a protein derived from beef heart mitochondria (I-protein) may have relevance to a physiological regulation of the enzyme. A protein has been isolated from the same source by Pullman and Monroy (26) which acts as an inhibitor of mitochondrial ATPase.

Although ATP served as the most effective phosphoryl donor in the exchange reaction, several other nucleoside triphosphates were also active donors. The low degree of specificity for the nucleoside triphosphates is not unique to this particular transferase. The same order of specificity reported herein, and previously (10), has also been reported by Löw et al. (27) for the phosphoryl acceptor properties of a group of nucleoside diphosphates (the assay system measured oxidative phosphorylation in the presence of submitochondrial particles derived from beef heart mitochondria). A soluble ATPase from beef heart mitochondria has been reported (28) to show a comparable lack of specificity for nucleoside triphosphates as phosphoryl donors. The same appears to be the case for the ATP-ADP exchange enzyme isolated from liver mitochondria (25). The apparent discrepancy between this lack of specificity in the systems cited above and the specificity of adenine nucleotides as phosphoryl acceptors during oxidative phosphorylation (27) and as phosphoryl donors during coupled reduction of NAD in intact mitochondria (29) may be explained on the basis of the topology of the reactions.

All of the reactions cited with low degrees of specificity may be involved in phosphorylative reactions of oxidative phosphorylation dealing with nucleotides bound to the cristae structure in the im mediate vicinity of energy conserving reactions. The adenine nucleotide specificity for oxidative phosphorylation catalyzed by intact mitochondria, on the other hand, would appear to be an attribute of subsequent transfer or kinase reactions. This is not meant to exclude the possibility of adenine nucleotide involvement in the early reactions of oxidative phosphorylation. Indeed, evidence exists which indicates that adenine nucleotide is involved quite early in the phosphorylation reactions during oxidative phosphorylation $(30,31,32,33,34)$. We are suggesting that the nonspecific reaction catalyzed by phosphoryl transferase may be involved in the transfer of the terminal phosphate of membrane-bound ATP, to ADP external to the mitochondrion and unable to interact directly with the compartment containing the bound A'TP. This possibility has been explored by Siekevitz and Potter (35).

From an examination of reactions [1] 
and [2] above it would appear that phosphoryl transferase would suit the requirements for $\mathrm{E}$ in that scheme for the pathway of phosphate transfer during oxidative phosphorylation. The data which may be marshalled to support such a role concern the ability of phosphoryl transferase to increase the phosphorylative capacity of poorly phosphorylating submitochondrial particles $(2,3,4)$, form a phosphoprotein during oxidative phosphorylation in both mitochondria $(5,6,7)$ and submitochondrial particles (8), receive a phosphoryl group from $\operatorname{ATP}(5,6)$ and catalyze an ATP-ADP exchange reaction (10). On the other hand, it has not been possible to provide direct evidence for such a role for phosphoryl transferase in oxidative phosphorylation since we have not been successful in establishing the nature of the physiological phosphoryl donor for phosphoryl transferase. For this reason, and because of the lack of inhibition of either the transferase activity or the ATP-ADP exchange reaction by oligomycin, we believe it likely that phosphoryl transferase does not serve as an obligatory phosphoryl intermediate of oxidative phosphorylation, but that this enzyme may serve to shuttle phosphoryl groups from bound ATP synthesized during oxidative phosphorylation to ADP external to the compartment in which oxidative phosphorylation occurs.

\section{ACKNOWLEDGMENTS}

The author expresses his gratitude to Professor David E. Green for his many courtesies during the course of this investigation, to Mr. Earl Fronk for skilled technical assistance, and to Mrs. Janet MacDonald and Mrs. Murlye Harris for help in the preparation of the manuscript.

\section{REFERENCES}

1. Sanadi, D. R., Ann. Rev. Biochem. 34, 21 (1965).

2. Beyer, R. E., Arch. Biochem. Biophys. 123, 41 (1968).

3. Beyer, R. E., Biochem. Biophys. Res. Commun. 16, 460 (1964).

4. Beyer, R. E., in "Methods in Enzymology" (Estabrook, R. W., and Pullman, M. E., eds.), Vol. X, p. 519. Academic Press, New York (1967).
5. Beyer, R. E., Biochem. Biophys. Res. Commun. 17, 184 (1964).

6. Beyer, R. E., Arch. Biochem. Biophys., 127, 43 (1968).

7. KEMP, JR., A., in Regulation of Metabolic Processes in Mitochondria, BBA Library, Vol. 7, Tager, J. M., Papa, S., Quagliariello, E, and Slater, E. C., Eds., Elsevier Publishing Co., Amsterdam, 1966, p. 264.

8. Beyer, R. E., Canad. J. Biochem. in press.

9. Lehninger, A. L., "The Mitochondrion," W. A. Benjamin, Inc., New York, 1964.

10. Beyer, R. E., Biochem. Biophys. Res. Commun. 17, 764 (1964).

11. Crane, F. L., Glenn, J. L., and Green, D. E., Biochim. Biophys. Acta 22, 475 (1956).

12. Hatefi, Y., and Lester, R. L., Biochim. Biophys. Acta 27, 83 (1958).

13. Beinert, H., Green, D. E., Hele, P., Hift, H., Von KorfF, R. W., and Ramakrishnan, C. V., J. Biol. Chem. 203, 35 (1953).

11. Brierley, G., and O'Brien, R. L., J. Biol. Chem. 240, 4532 (1965).

15. Pabst Laboratories Circular OR-10, 1956, p. 20.

16. Gornall, A. G., Bardawill, C. J., and David, M. M., J. Biol. Chem. 177, 751 (1949).

17. Chappell, J. B., and Crofts, A. R., Biochem. J. 95, 707 (1965).

18. Wadkins, C. L., and Glaze, R. P., in "Oxidases and Related Redox Systems" (T. E. King, H. S. Mason, and M. Morrison, eds.), Vol. 2, p. 1018. John Wiley and Sons, Inc., New York (1965).

19. Green, D. E., and Burkhard, R. K., Arch. Biochem. Biophys. 92, 312 (1961).

20. Fleischer, S., and Fleischer, B., "Methods in Enzymology" (R. W. Estabrook, and M. E. Pullman, eds.), Vol. X. p. 406. Academic Press, New York (1967).

21. LindberG, O., and Ernster, L., in "Methods of Biochemical Analysis" (D. Glick, ed.), Vol. 3, p. 1. Interscience Publ., New York (1956).

22. Morton, R. K., Biochem. J. 65, 674 (1957).

23. Kaufman, S., Gilvarg, C., Cori, O., and Ochoa, S., J. Biol. Chem. 203, 869 (1953).

24. Beyer, R. E., J. Biol. Chem. 236, 236 (1961).

25. Goffean, A., Pedersen, P. L., and Lehninger, A. L., J. Biol. Chem. 242, 1845 (1967).

26. Pullman, M. E., and Monroy, G. C., J. Biol. Chem. 238, 3762 (1963).

27. Löw, H., Vallin, I., AND Alm, B., "Energy Linked Functions of Mitochondria" (B. Chance, ed.), p. 5. Academic Press, New York (1963).

28. Pullman, M. E., Penefsky, H. S., Datta, A., and Racker, E., J. Biol. Chem. 235, 3322 (1960). 
29. Chance, B., J. Biol. Chem. 236, 1569 (1961).

30. Cooper, C., Biochemistry 4, 335 (1965).

31. HeldT, H. W., Jacobs, H., and KlingenberG, M., Biochem. Biophys. Res. Commun. 18, 174 (1965).

32. Skulachev, V. P., Nature 198, 444 (1963).

33. Skulachev, V. P., in Abstracts, 6th International. Cong. Biochem., X, New York, 1964, p. 758.
34. Skulachev, V. P., Evtodienko, Yu. V., Smirnova, E. G., Christyakov, V. V., and Jasaitis, A. A., in Mitochondrion, Structure and Function (S. E. Severin, ed.), USSR Academy Press, Moscow, 1966, p. 100.

35. Siekevitz, P., and Potter, V. R., J. Biol. Chem. 215, 237 (1955). 